\title{
Cardiac Magnetic Resonance in heart transplant patients: diagnostic value of quantitative tissue markers (T2 mapping and ECV) for acute cardiac rejection diagnosis
}

\author{
Emmanuelle Vermes ${ }^{*}$, Clemence Pantaleon ${ }^{1}$, Julien Pucheux ${ }^{1}$, Michel Aupart ${ }^{2}$, Nicolas Cazeneuve ${ }^{1}$, \\ Laurent Brunereau'
}

From 19th Annual SCMR Scientific Sessions

Los Angeles, CA, USA. 27-30 January 2016

\section{Background}

The diagnosis of acute cardiac rejection (AR) still requires invasive technique with endomyocardial biopsy (EMB) which has important risks and limitations.

Cardiac Magnetic Resonance (CMR) with recently T2 and T1 mapping is a promising technique for characterizing myocardial tissue.

The purpose of the study was to evaluate T2, T1 and extracellular volume (ECV) quantification as novel tissue markers to diagnose acute cardiac rejection.

\section{Methods}

CMR was prospectively performed in heart transplant patients within $6 \pm 13$ days of routine EMB and before acute rejection therapy. Images were acquired on a 1.5 Tesla scanner including T2 mapping (T2 prepared-SSFP) and T1 mapping using a modified look locker inversion recovery sequence (MOLLI) at basal, mid and apical level in short axis view.

$\mathrm{T} 2$ and $\mathrm{T} 1$ values were measured before and 15 minutes (for T1 mapping) after contrast administration. The results are expressed by the median and the $5^{\text {th }}$ and the $95^{\text {th }}$ percentiles.

\section{Results}

Twenty five patients (age $56 \pm 14$ years) were included providing 38 comparisons CMR/EMB. Acute rejection (cellular, humoral or clinical symptoms) was diagnosed in 11 patients.
Patients with AR had significantly higher global T2 values at 3 levels (59 ms [54-63] vs $51 \mathrm{~ms}$ [49-55], $\mathrm{P}=$ 0.0025 at basal; $57 \mathrm{~ms}$ [55-65] vs $52 \mathrm{~ms}$ [50-54], $\mathrm{P}=0.001$ at median and $60 \mathrm{~ms}$ [54-66] vs $55 \mathrm{~ms} 51-57], \mathrm{P}=0.013$ at apical level). The area under the curve (AUC) for each level was: $0.83 ; 0.58$ and 0.77 respectively.

Patients with AR had significantly higher ECV at basal and median level: $35 \%$ [33-39] vs $27 \%$ [25-31] $\mathrm{P}=0.003$ and $33 \%$ [28-39] vs $27 \%$ [24-31], $\mathrm{P}=0.025$ respectively. The AUC for each level was; 0.85 and 0.75 respectively.

The sensitivity, specificity and diagnosis accuracy for basal T2 (cutoff : $57.7 \mathrm{~ms}$ ) were $70 \%, 96 \%$ and $79 \%$ respectively; basal ECV: (cutoff $31.2 \%$ ) $89 \%, 77 \%$ and $81 \%$ respectively. The best AUC (0.88) was obtained when we combined basal T2 and basal ECV.

\section{Conclusions}

In heart transplant patients, a combined CMR approach using T2 mapping and ECV quantification provides a high diagnostic accuracy for acute rejection diagnosis and could potentially decrease the number of routine EMB. Further studies are required to confirm these data.

\footnotetext{
Authors' details

${ }^{1}$ Cardiac imaging, CHU Trousseau, Tours, France. ${ }^{2}$ Heart surgery, $\mathrm{CHU}$

Trousseau, Tours, France.
}

Published: 27 January 2016

${ }^{1}$ Cardiac imaging, CHU Trousseau, Tours, France

Full list of author information is available at the end of the article 
doi:10.1186/1532-429X-18-S1-047

Cite this article as: Vermes et al:: Cardiac Magnetic Resonance in heart transplant patients: diagnostic value of quantitative tissue markers (T2 mapping and ECV) for acute cardiac rejection diagnosis. Journal of Cardiovascular Magnetic Resonance 2016 18(Suppl 1):047.

Submit your next manuscript to BioMed Central and take full advantage of:

- Convenient online submission

- Thorough peer review

- No space constraints or color figure charges

- Immediate publication on acceptance

- Inclusion in PubMed, CAS, Scopus and Google Scholar

- Research which is freely available for redistribution

Submit your manuscript at www.biomedcentral.com/submit 